\title{
Proteomic analysis of the excretion-secretion products of four Trichinella spiralis isolates obtained from accidental hosts
}

\author{
Luz Ofelia Franco-Sandoval ${ }^{1}$,Enedina Jiménez-Cardoso ${ }^{1 *}$, Héctor Quezada-Pablo ${ }^{2}$ and \\ Ana Laura Guzmán-Ortiz²
}

${ }^{1}$ Laboratorio de Investigación en Parasitología; ${ }^{2}$ Laboratorio de Investigación en Inmunología y Proteómica. Hospital Infantil de México Federico Gómez, Mexico City, Mexico

\begin{abstract}
Background: Trichinella spiralis is an intestinal and tissue nematode-specific for mammalian skeletal muscle, causing a series of physiological alterations. T. spiralis excretory-secretion products (ESP) play an important role in the appearance and regulation of these alterations. However, the effect of these products on the infection and invasion of the parasite to the host is unknown. Methods: Differences and similarities between antigenic proteins and surface proteins of four incidental hosts isolates (dogs) of T. spiralis and the reference strain isolated from pigs (MSUS/MEX/91/CM) were assessed by electrophoresis, western blot, and mass spectrometry. Results: Five proteins exclusive to the incidental hosts were analyzed using gene ontology. The results showed that these proteins are part of the extracellular matrix of the parasite, present catalytic activity, and bind to host cells. The antigenic activity of the four strains showed the antigenic triplet characteristic of T. spiralis of 43 , 45 and $47 \mathrm{kDa}$. Conclusions: Five proteins exclusive to dog isolates provided information to understand the mechanism of action of this parasite to penetrate the muscle and evade the immune response in the host.
\end{abstract}

Key words: Trichinella spiralis. Excretion-secretion products (ESP). Mass spectrometry. Muscle larvae.

\section{Análisis proteómico de los productos de excreción-secreción de cuatro aislados de Trichinella spiralis obtenidos de hospederos accidentales}

\section{Resumen}

Introducción: Trichinella spiralis es un nemátodo tisular que se aloja en el músculo esquelético de humanos y otros mamíferos y causa una serie de alteraciones fisiológicas. Las proteínas de los productos de excreción-secreción de T. spiralis juegan un papel importante en la aparición y regulación de estas alteraciones. Sin embargo, aún no se conoce el efecto de estos productos en la infección e invasión del parásito al hospedero. Métodos: Mediante un análisis electroforético en una dimensión, Western blot y espectrometría de masas, se evaluaron las diferencias y similitudes entre proteínas antigénicas y de superficie de cuatro aislados de T. spiralis obtenidos de hospederos accidentales (perros) y la cepa de referencia aislada de cerdos (MSUS/MEX/91/CM). Resultados: Utilizando ontología de genes, se encontraron cinco proteínas exclusivas de los hospederos accidentales. Después del análisis, se encontró que estas proteínas forman parte de la matriz extrace-

\section{Correspondence:}

*Enedina Jiménez Cardoso

Email: jimenezce@yahoo.com.mx
DOI: 10.24875/BMHIME.M17000015
Available online: 25-06-2018 Bol Med Hosp Infant Mex. 2017;74:425-431

www.bmhim.com

2444-3409/@ 2018. Hospital Infantil de México Federico Gómez, published by Permanyer México SA de CV, all rights reserved. 
lular del parásito, cuentan con actividad catalítica y están implicadas en la adhesión a las células del hospedero. La actividad antigénica de las cuatro cepas aisladas de hospederos accidentales es idéntica a la reportada para T. spiralis, visualizándose el triplete antigénico característico de 43, 45 y 47 kDa. Conclusiones: Las proteínas exclusivas de los hospederos accidentales proveen información para entender el mecanismo de acción de este parásito para penetrar el músculo y evadir la respuesta inmune en el hospedero.

Palabras clave: Trichinella spiralis. Productos de excreción-secreción (PES). Espectrometría de masas. Larva muscūlar.

\section{Introduction}

Trichinellosis is a zoonotic disease caused by nematodes of the genus Trichinella, consisting of eight species and four genotypes ( $T$. spiralis, $T$. native, T. murrelli, T. britovi, T. nelsoni, T. pseudospiralis, T. papue, T. zimbabwensis, T-6, T-8, T-9, and T-12). ${ }^{1-3}$ These species are distributed throughout the world and are widespread, affecting carnivores, humans and incidental hosts. ${ }^{4}$ Between 2004 and 2009, there were 15 outbreaks of human trichinellosis in China, with 1,387 cases and four deaths. In Mexico, particularly in Zacatecas, approximately 758 cases of human trichinellosis were reported during the period between 1952 and 1997. Most outbreaks occurred due to consumption of raw or undercooked pork. ${ }^{5}$ Between 1970 and 1990, eight cases of trichinellosis were reported in children whose diagnosis was made through epidemiological, clinical and laboratory tests. The highest frequency occurred in the group between 10 to 14 years, coming from a low socioeconomic level. ${ }^{6}$ Currently, there are about 11 million people infected by nematodes of the genus Trichinella spp. ${ }^{7}$

The importance of trichinellosis in incidental hosts such as the dog was demonstrated in studies conducted in China, where 13 provinces were analyzed. In the municipal butcher shops, a prevalence of $16.2 \%$ was found, with a range of 1.2 to $44.8 \%$, while the prevalence found in the markets was $3.5 \%$, which represented a serious public health problem.

In countries such as Finland, the risk of trichinellosis in domestic dogs was reported in $19.4 \%$, while infection with $T$. native was found more frequently in multi parasitized free-living dogs with other Trichinella species. Therefore, the possibility of infection when the meat of these animals, raw or undercooked, is ingested by humans and synanthropic hosts is increased. ${ }^{8,9}$ In this way, the possibility of contracting this parasitic increases by having more hosts with infection potential, and opens new routes of infection for humans.

It is important to point out that trichinellosis is a potentially deadly zoonosis, so it is imperative to know all the probable sources and the mechanism of infection of the parasite, as well as to analyze the proteins involved in pathogenicity and infection. Because it is a disease that is still poorly diagnosed and confused with other gastrointestinal disorders, the preceding will provide adequate tools for treatment.

\section{Methods}

\section{Animals and treatment}

Wistar rats were infected intragastrically with approximately 1000 L1 larvae. Thirty days post-infection, animals were sacrificed. The infective larvae were extracted from skeletal muscle by artificial digestion, using $1 \%$ pepsin- $\mathrm{HCl}$ at $37^{\circ} \mathrm{C}$ in constant agitation for three hours.

The handling of animals was carried out according to the official norms and guidelines of the Ethics Committee of the Hospital Infantil de México Federico Gómez.

\section{Obtaining excretion-secretion products of Trichinella spp L1 larvae}

The larvae obtained by artificial digestion were kept in culture boxes under an atmosphere of $5 \% \mathrm{CO}^{2}$ at $37{ }^{\circ} \mathrm{C}$ for 20 days. Subsequently, the concentration of the excretion-secretion products (ESP) was determined.

\section{Electrophoresis of the excretion-secretion products of $T$. spiralis larvae}

Once the concentration was calculated, $2.5 \mu \mathrm{g}$ of protein were analyzed by electrophoresis in $10 \%$ acrylamide/bisacrylamide gels (SDS-PAGE). The gels were stained with silver. The protein samples were subsequently analyzed by Western blot.

\section{Preparation of the protein sample}

For the ESP sample, $500 \mu$ l of lysis buffer ( $4 \%$ SDS, $100 \mathrm{mM}$ DTT, $100 \mathrm{mM}$ Tris pH 8.6, and Thermo Scientific Halt Protease Inhibitor Cocktail) were added. The 
mixture was incubated at $40{ }^{\circ} \mathrm{C}$ for $30 \mathrm{~min}$ to reduce the proteins. Subsequently, Tris was added to a final concentration of $300 \mathrm{mM}$ and $200 \mathrm{mM}$ iodine acetamide (IAM) to alkylate the protein mixture, which was incubated at room temperature and in darkness for $30 \mathrm{~min}$. The proteins were precipitated by adding nine volumes of absolute ethanol, incubating at $-20^{\circ} \mathrm{C}$ overnight. The proteins were solubilized in $50 \mathrm{mM}$ guanidinium chloride and $20 \mathrm{mM}$ Tris. Proteolytic digestion was performed with trypsin 1:50, incubating overnight at $37^{\circ} \mathrm{C}$.

The peptide mixture was acidified to $0.1 \%$ with trifluoroacetic acid (TFA) and desalted in Sep-Pak ${ }^{\circledR}$ C18 cartridges. The peptides were washed three times with $0.1 \%$ TFA and subsequently eluted with $1 \mathrm{ml}$ of $60 \%$ acetonitrile and $0.1 \%$ TFA. The eluted solution was completely dried using a SpeedVac ${ }^{\circledR}$ centrifuge, and the dried peptides were frozen at $-80^{\circ} \mathrm{C}$.

\section{Protein identification by liquid chromatography coupled to mass spectrometry}

The peptide mixture was resuspended in $50 \mu \mathrm{l}$ of $0.1 \%$ formic acid, and then placed in an injection vial to be separated in an Ultimate 3000 RSLC nano HPLC (Thermo Scientific ${ }^{\circledR}$ ) by a pre-concentration column of PepMap100 C18, 5um, $100 \AA$ (Thermo Scientific ${ }^{\circledR}$ ) connected to analytical column $\mathrm{C} 18$ of $75 \mu \mathrm{m}$ internal diameter and $15 \mathrm{~cm}$ long (Agilent Technologies ${ }^{\circledR}$ ). The peptides were eluted with a non-linear gradient of $2 \%$ to $40 \%$ solution B $(0.1 \%$ formic acid in acetonitrile) for $240 \mathrm{~min}$ at $250 \mathrm{nl} / \mathrm{min}$, and analyzed online in a quadrupole-TOF mass spectrometer Impact II (Bruker Daltonics $\left.{ }^{\circledR}\right)$, which was operated in positive mode with a CaptiveSpray ${ }^{\circledR}$ source.

\section{Proteomic data analysis}

The mass spectra were processed using the Data Analysis program (Bruker Daltonics ${ }^{\circledR}$ ) and compared with the SwissProt ${ }^{\circledR}$ protein database, using the Mas$\cot ^{\circledR}$ search engine. The data were searched with a peptide mass tolerance of $7 \mathrm{ppm}$ and with a tolerance of $0.05 \mathrm{Da}$ and a minimum peptide length of five amino acids for the fragmentation products. Cysteine carbamidomethylation was considered as fixed modification and oxidation of methionine as a variable. Up to two cutting omissions of the trypsin protease were allowed. The comparison of the proteins identified in each one of the replicates in control and the experimental sample was made using Venn diagrams. (http://genevenn.

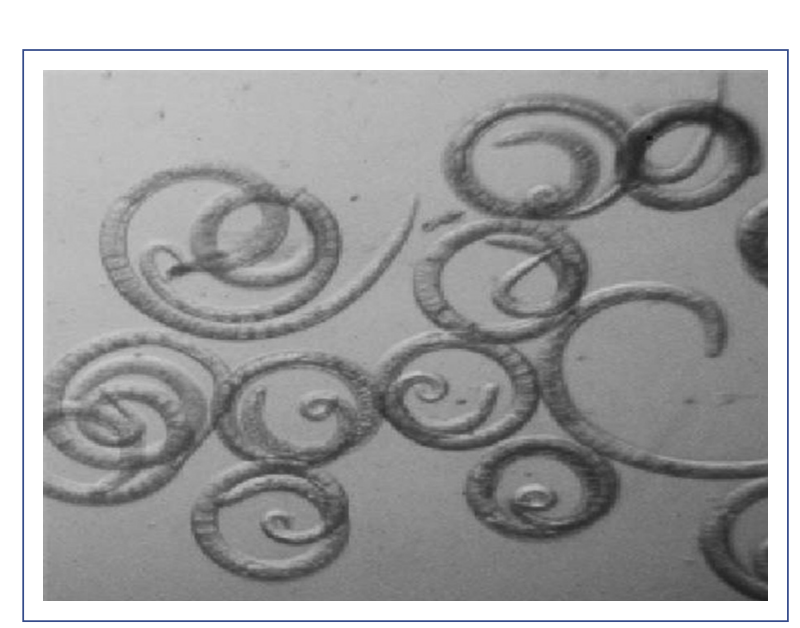

Figure 1. Larvae L1 of Trichinella spiralis. Larvae obtained by the technique of artificial digestion and recovered using the modified Baermann funnel. Inverted microscope (40X).

sourceforge.net/usm.edu, implemented by Mehdi Pirooznia). Only the proteins that were in the three replicates of each sample were taken as valid for the comparison between the control sample and the experimental sample.

\section{Characterization of proteins by gene ontology}

Exclusive proteins from incidental hosts were categorized using Web Gene Ontology Annotation Plot (http://wego.genomics.org.cn/cgi-bin/wego/index. pl). ${ }^{10,11}$ The data of these proteins were analyzed and compared, showing the characteristic biological functions in a graph.

\section{Results}

\section{Animals and treatment}

The biological cycle of Trichinella spiralis was reproduced in Wistar rats inoculated intragastrically with $\mathrm{L} 1$ larvae. We obtained 20,000 L1/Ml larvae of the Z1, Z2, $\mathrm{Z3}$ and $\mathrm{Z4}$ isolates of $T$. spiralis, as well as the strain derived from a pig (Fig. 1).

\section{Excretion-secretion products from L1 larvae of $T$. spiralis and the strains obtained from incidental hosts}

ESPs were collected weekly, measuring the concentration of proteins in the culture medium with the Epoch 


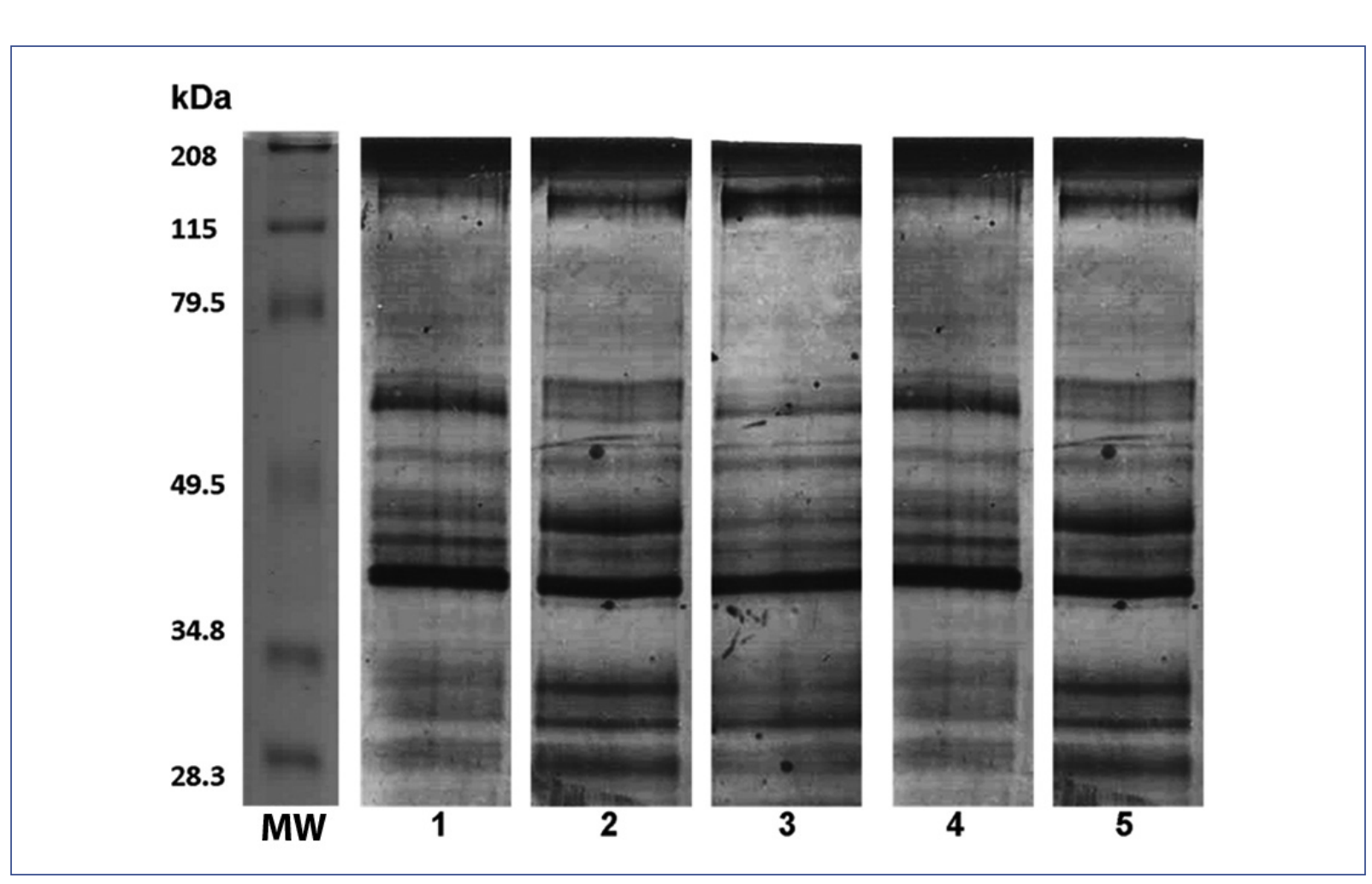

Figure 2. Electrophoresis of the excretion-secretion products.Lanes: 1, ESP of the reference strain Trichinella spiralis; 2, ESP Z1; 3, ESP Z2; 4, ESP Z3; 5, ESP Z4. All ESP detected by 10\% electrophoresis and stained with silver. Differences and similarities in the protein profile are observed. MW, molecular weight marker.

Gen5 ${ }^{\circledR}$ spectrophotometer. The concentration range ranged between 0.5 and $4.5 \mu \mathrm{g} / \mu \mathrm{l}$.

\section{Electrophoresis of the excretion-secretion products from larvae of $T$. spiralis}

The electrophoresis was performed to know the total of proteins expressed in the ESP of each strain and, depending on the protein profile, analyze if there were differences or similarities between them, taking as a point of comparison the strain of $T$. spiralis obtained from pig (Fig. 2).

\section{Western blot}

Rabbits were inoculated to obtain polyclonal anti-ESP antibodies from each strain. The serum was obtained, and the ELISA technique was performed to verify the presence of this antibodies. The cut-off point was $0.995 \mathrm{~nm}$. Those that exceeded this threshold were considered positive and were analyzed by Western blot.

Figure 3 shows the antigenic triplet characteristic of T. spiralis of 43,45 and $47 \mathrm{kDa}$, corroborating that, indeed, Z1, Z2, Z3, Z4, and the reference strain share antigenic proteins.

Differences were found in the expression of high molecular weight proteins, between 110 and $180 \mathrm{kDa}$. These results showed the different antigenicity among the samples analyzed. The difference between the expressed proteases and the protein profile in the ESP allowed demonstrating that the expression of proteins in the different isolates of the parasite is related to the function of the isolate itself and the parasitic host.

\section{Identification and analysis of proteins by liquid chromatography coupled to masses}

Five exclusive proteins were identified for $T$. spiralis samples from incidental hosts about the reference strain obtained from pig (Fig. 4). These exclusive proteins, since they have proteolytic functions, could confer greater pathogenicity to the parasite. The ability of these strains to penetrate the skeletal muscle and establish the disease is higher compared to the reference strain (Table 1). 

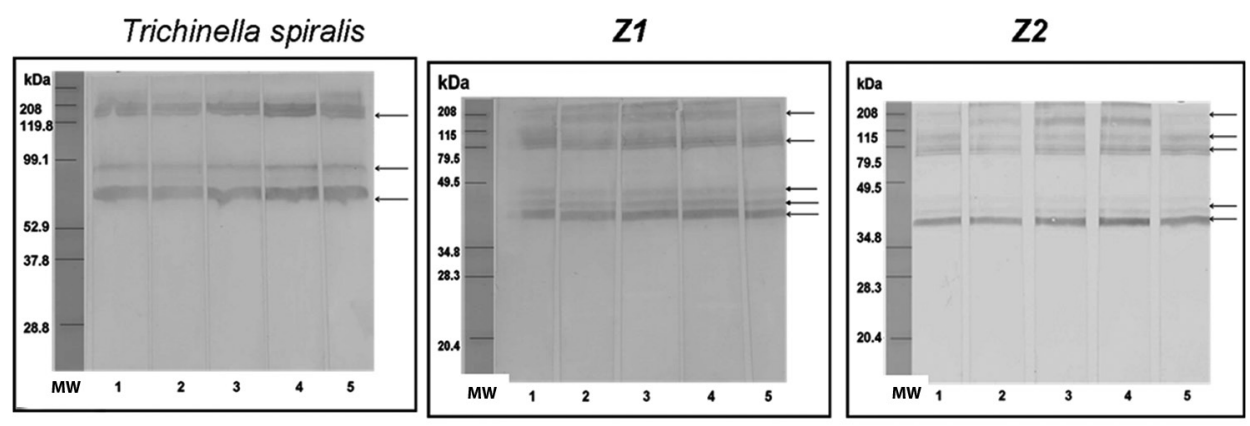

Z3
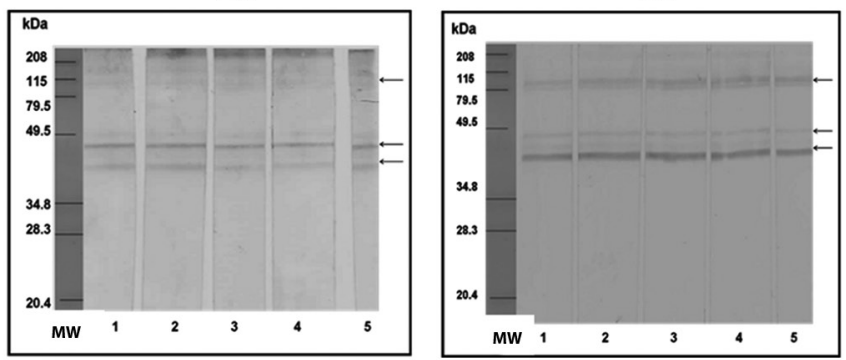

Figure 3. Western blot. ESP of the isolates and the reference strain were used as antigens and the serum obtained from the immunized rabbits as antibodies. ESPs of Trichinella spiralis were first tested as antigens against $T$. spiralis serum, and each serum of Z1, Z2, Z3 and Z4 strains. Subsequently, the Z1 strain was analyzed and exposed to the different serums in the same order, as well as Z2, Z3, and Z4. The arrows indicate the shared and expressed antigenic proteins. MW, molecular weight marker.

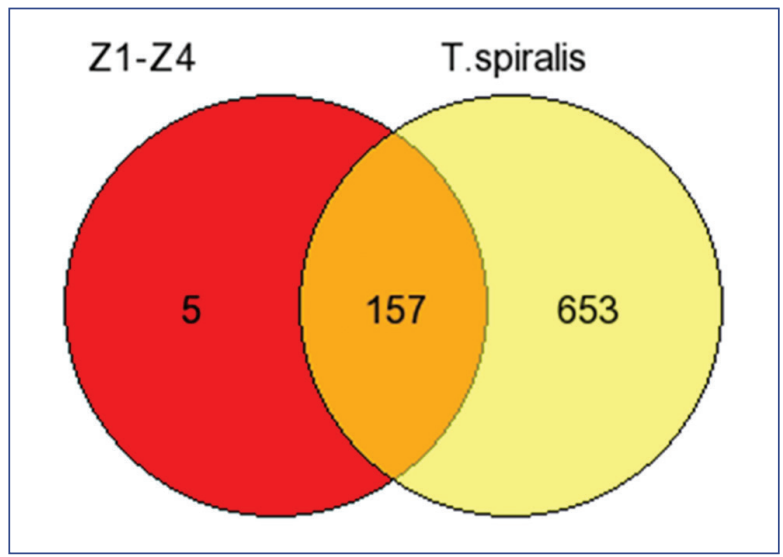

Figure 4. Protein analysis. A Venn diagram representing the 157 proteins shared between the strain of $T$. spiralis from incidental hosts and $T$. spiralis recovered from pigs is shown, indicating that there are only five proteins exclusive to samples from incidental hosts. Only the proteins present in the four strains from incidental hosts were compared against the proteome of $T$. spiralis.

\section{Characterization of proteins by gene ontology}

To a better understanding of the functions of the identified proteins, the WEGO (Web Gene Ontology
Annotation Plot) program was used, categorizing the proteins into two groups: those with molecular functions and those immersed in biological processes (Figure 5). The five proteins analyzed in this study are part of the extracellular matrix of the parasite and have catalytic and binding to host cells activity.

The identified proteins have molecular functions corresponding to the formation of the extracellular matrix of the parasite, catalytic activity and binding to host cells.

\section{Discussion}

The proteins present in the ESP play an essential role in the invasion, the evasion of the immune system and the adaptation between parasites and the immune response of the host. ${ }^{12}$

In an analysis conducted by Nagano et al. in 2009, three main proteins were found: 43,53 and $45 \mathrm{kDa} .{ }^{13}$ The authors established that the host mostly recognizes these glycoproteins during infection. Ortega et al., in 1989, found 28 proteins in a molecular weight range between 11 and $200 \mathrm{kDa} .{ }^{14}$ Our results agree with these authors since the ESP of the Z1, Z2, Z3, Z4 and the reference strain isolates showed proteins in a range of 28 to $200 \mathrm{kDa}$, besides presenting the glycoproteins of 43 and $45 \mathrm{kDa}$. 
Table 1. Characteristics of proteins exclusive of incidental hosts

\begin{tabular}{|c|c|c|c|c|c|}
\hline Protein ID & Protein & Access No. & Characteristics & \multicolumn{2}{|l|}{ Gene } \\
\hline 1 & $\begin{array}{l}\text { CDGSH iron-sulfur } \\
\text { domain-containing protein } 1\end{array}$ & A0A0V1ARP2 & Iron and sulfur-binding protein & Cisd1 & $\stackrel{\infty}{\infty}$ \\
\hline 2 & Cathepsin L & A0A0V1B2U5 & $\begin{array}{l}\text { Peptidase activity of cysteine-type. } \\
\text { Integral membrane component }\end{array}$ & Cp1 & $\underset{\frac{\Phi}{\sigma}}{\stackrel{ \pm}{c}}$ \\
\hline 3 & Collagen alpha-1 (IV) chain & A0A0V1B3L0 & $\begin{array}{l}\text { Structural constituent of the } \\
\text { extracellular matrix }\end{array}$ & emb-9 & $\frac{1}{2}$ \\
\hline 4 & Laminin subunit alpha-2 & A0A0V1BAN4 & $\begin{array}{l}\mathrm{Ca}^{++} \text {mediated receptor protein that } \\
\text { may have binding sites for steroids }\end{array}$ & Lama1 & $\frac{1}{\square}$ \\
\hline 5 & $\begin{array}{l}\text { Putative parathyroid hormone } 2 \\
\text { receptor }\end{array}$ & E5S945 & Unknown & Tsp_00 & $\frac{65}{2}$ \\
\hline
\end{tabular}

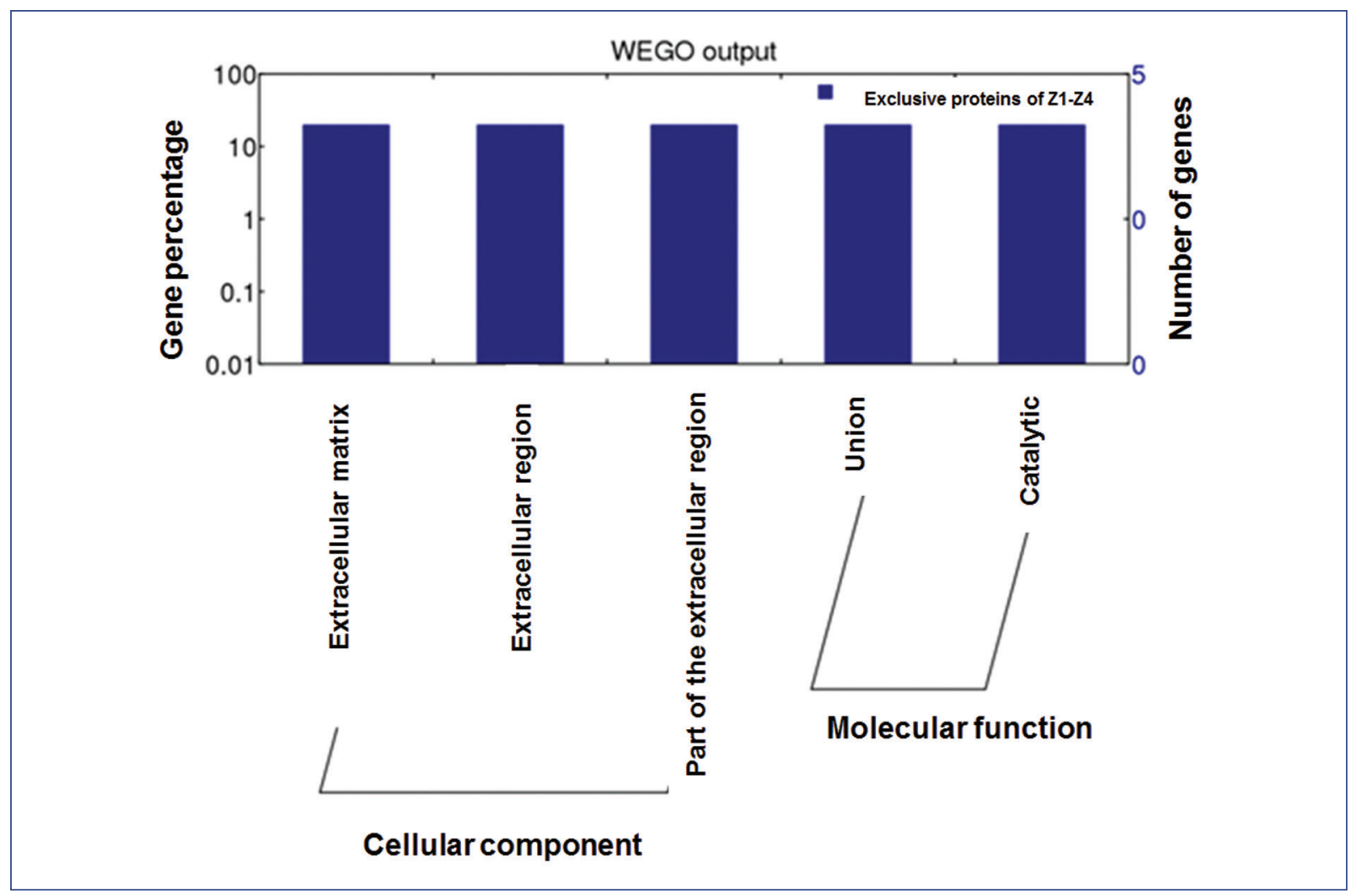

Figure 5. Gene ontology of the ESP of T. spiralis and four strains obtained from incidental hosts. The identified proteins have molecular functions corresponding to the formation of the extracellular matrix of the parasite, and the catalytic activity and binding to host cells.

The proteomic analysis showed proteases that participate in the host-parasite interaction. This data is of great relevance since many pathogens use these proteins to facilitate the entry of parasites to the host's target cell, initiating infection and evasion of the immune response. Extracellular proteins and binding to host cells proteins were also found.
Regarding the Western blot, all the isolates showed the triplet of proteins 43,45 and $47 \mathrm{kDa}$, corresponding to glycoproteins containing tivelosa as an antigenic agent. These proteins have already been molecularly characterized and are known to be important in the formation of the nurse cell and the transformation of muscle cells. ${ }^{14}$ 
It should be noted that we found differential expression of proteins that have a high molecular weight between 110 and $180 \mathrm{kDa}$.

This work allowed us to analyze the antigenic characteristics of $T$. spiralis and identify proteins, shared and exclusive, of strains obtained from incidental hosts (not previously reported) against the reference strain isolated from pigs (the usual host of this nematode).

It was important to analyze the participation of this new host in the biological cycle of $T$. spiralis since it could be an indirect way of transmitting this disease to humans by infecting feral pigs used for human consumption. In this paper, we present the bases for future research on the mechanisms of indirect transmission to humans.

The analysis of the ESP of larvae of $T$. spiralis obtained from incidental hosts showed the presence of five proteins different from those reported in the isolated pig reference strain.

According to the analysis by Western blot, these proteins have greater pathogenicity about the reference strain and present a different pattern of proteases, which gives them greater invasive power. The analysis of these proteins is important, since genetic information can be transferred for translation from incidental hosts to habitual hosts of this parasite, and if so, very often the infection to humans would be more severe and lethal.

In strains isolated from dogs, proteins of greater invasion to host cells are presented, so the analysis and use of these proteins could serve as an early diagnosis by not presenting a cross-reaction with other helminths, such is the case with the T. spiralis isolated from pigs.

\section{Ethical disclosures}

Protection of human and animal subjects. The authors declare that no experiments were performed on humans or animals for this study.
Confidentiality of data. The authors declare that they have followed the protocols of their work center on the publication of patient data.

Right to privacy and informed consent. The authors declare that no patient data appear in this article.

\section{Conflict of interest}

The authors declare no conflicts of interest of any nature.

\section{References}

1. Bandi C, La Rosa G, Comincini S, Damiani G, Pozio E. Random amplified polymorphic DNA technique for the identification of Trichinella species. Parasitology. 1993;107:419-24.

2. Meslin F, Stöhr K, Heymann D. Public health implications of emerging zoonoses. Rev Sci Tech. 2000;19:310-7.

3. Murrell K, Lichtenfels R, Zarlenga DS, Pozio E. The systematics of the genus Trichinella with a key to species. Vet Parasitol. 2000;93:293-307.

4. Ortega-Pierres M, Arriaga C, Yépez-Mulia L. Epidemiology of trichinellosis in Mexico, Central and South America. Vet Parasitol. 2000;93:201-25.

5. Cabral J, Villacaña H, Fragoso R, Contreras A. Perfil epidemiológico de la triquinosis en el Estado de Zacatecas. Salud Publica Mex. 1990;32: 575-82.

6. Yang Y, Zhang Z, Yang J, Chen X, Cui S, Zhu X. Oral vaccination with Ts87 DNA vaccine delivered by attenuated Salmonella typhimurium elicits a protective immune response against Trichinella spiralis Tarval challenge. Vaccine. 2010;28:2735-42.

7. Tay ZJ, Sánchez VJ, Ruiz SD, Calderón RL, García YY, Alonso T, et al. Estado actual de nuestros conocimientos sobre trichinellosis en la República Mexicana: reporte de nuevas localidades infectadas. Rev Fac Med UNAM. 2004;3:96-100.

8. Viveros N, Arriaga C, Banda V, Ortega-Pierres MG, Yépez-Mulia L. Detection of Trichinella infection in slaughter horses by artificial digestion, ELISA and PCR. Parasite. 2001;8:S257-9.

9. Berumen V, Muñoz J, Moreno M. Trichinellosis in dogs from Zacatecas, México. Parasitol Latinoam. 2002;57:72-4.

10. Cui J, Liu R, Wang L, Zhang X, Jiang P, Liu M, et al. Proteomic analysis of surface protein of Trichinella spiralis muscle larvae by two-dimensional gel electrophoresis and mass spectrometry. Parasit Vectors. 2013;6:355.

11. Ye J, Fang L, Zheng H, Zhang Y, Chen J, Zhang Z, et al. WEGO: a web tool for plotting GO annotations. Nucleic Acid Res. 2006;34:W293-7.

12. Liu $L$, Blaxter $M$, Shi $A$. The $5 s$ ribosomal RNA intergenic region of parasitic nematodes variation in size and presence of SLI RNA. Mol Biochem Parasitol. 1996;83:235-9.

13. Nagano I, Wu Z, Yakahashi Y. Functional genes and proteins of Trichinella sp. Parasitol Res. 2009;104:197-207.

14. Ortega-Pierres G, Muñiz E, Coral-Vázquez R, Parkhouse RM. Protection against Trichinella spiralis induced by purified stage-specific surface antigens of infective larvae. Parasitol Res. 1989;75:563-7. 